\title{
THE ANTI COVID-19 VACCINATION INTENTION OF MEDICAL PERSONNEL FROM ROMANIA
}

\author{
Dr. Daniela Rajka, \\ Cluj-Napoca school medical office
}

\begin{abstract}
INTRODUCTION: Vaccination is the only way to achieve group immunity in the SARS CoV-2 pandemic. Efforts to create safe vaccines worldwide have led to 60 vaccines being clinically evaluated at the moment according to the WHO, and the European Medicines Agency has urgently authorized the BioNTech / Fosun Pharma / Pfizer vaccine, a vaccine based on the mRNA technique.

OBJECTIVES: The study looks at the acceptability and intent of COVID-19 vaccination among medical staff.

MATERIAL AND METHODS: The study was conducted between November $3^{\text {rd }}$ and November $12^{\text {th }}$ 2020 , by distributing an anonymous questionnaire in online professional groups of medical staff regarding the acceptance of vaccination in general, and vaccination against COVID-19 in particular.

RESULTS: 612 persons answered to the survey, 164 nurses and 448 doctors.

207 doctors work in the hospitals, 103 in ambulatory care clinics, 76 in school medical offices and 62 in family doctors offices.

565 respondents $(92,3 \%)$ support vaccination in general, while $47(7,7 \%)$ do not.

$43,3 \%$ of the medical staff that were a part of this study were vaccinated against influenza this season. $80 \%$ of the medical staff supports vaccination against COVID-19, in general, and $47 \%$ of the respondents state that they will get vaccinated against COVID-19.

CONCLUSIONS: The Romanian medical staff supports the vaccination against COVID-19, and the safe vaccination intention is $47 \%$.

KEY WORDS: vaccination intention, anti COVID-19 vaccination, medical personnel
\end{abstract}

\section{INTRODUCTION}

The installation of group immunity in SARSCoV-2 infection is estimated at $67 \%$. There are two possibilities to achieve widespread immunity against SARS-CoV-2: (1) a mass vaccination campaign, with safe vaccines, or (2) the natural immunization of the population, over time. But the consequences of the latter are extremely serious, as it involves mass infection of the population and millions of deaths [1].

A study on survivors of SARS-CoV-2 infection, persons that needed hospital admission for their illness, showed that approximately $90 \%$ have protective antibodies and approximately $50 \%$ have a strong T lymphocyte response. Nevertheless, studies on outpatients are needed in order to assess the level of protective antibodies after mild infections [2].

In this context, the urgency of discovering a vaccine effective against COVID-19 is very high, and research for the production of a vaccine are numerous worldwide. However, the safety of citizens remains a key priority, so the European Commission considers that quality, safety and efficacy standards in the authorization of these vaccines must be strictly adhered to [3].

According to the World Health Organization, on 29.12.2020 there were 60 vaccines worldwide in the clinical evaluation stage and 172 vaccines in the pre-clinical evaluation stage [4]. The types of candidate vaccines in the clinical evaluation stage are presented in Table no. 1, and a classification according to the number of doses and the route of administration - in Table no. 2.

\footnotetext{
* Corresponding author: Daniela Rajka, Cluj-Napoca school medical office, e-mail: rajkadani07@yahoo.com Article received: 31.12 .2020 , accepted: 4.01.2021, published: 10.01.2021

Citing: Rajka D. Journal of School and University Medicine 2020;7(4):10-16
} 
Articole științifice

\begin{tabular}{|l|l|c|c|}
\hline \multicolumn{1}{|c|}{ Platform } & \multicolumn{1}{c|}{ Tip de vaccin } & \multicolumn{2}{c|}{ Candidate vaccines (no. and \%) } \\
\hline PS & Protein subunit & 18 & $30 \%$ \\
\hline VVnr & Viral Vector (non-replicating) & 9 & $15 \%$ \\
\hline DNA & DNA & 8 & $13 \%$ \\
\hline IV & Inactivated Virus & 8 & $13 \%$ \\
\hline RNA & RNA & 7 & $12 \%$ \\
\hline VVr & Viral Vector (replicating) & 4 & $7 \%$ \\
\hline VLP & Virus Like Particle & 2 & $3 \%$ \\
\hline VVr + APC & VVr + Antigen Presenting Cell & 2 & $3 \%$ \\
\hline LAV & Live Attenuated Virus & 1 & $2 \%$ \\
\hline VVnr + APC & VVnr + Antigen Presenting Cell & 1 & $2 \%$ \\
\hline & & 60 & \\
\hline
\end{tabular}

Table no. 1 Candidate vaccines, in clinical evaluation stage, according to the WHO - 29.12.2020 [4]]

\begin{tabular}{|c|c|c|c|}
\hline \multicolumn{2}{|c|}{ Dosage \& schedule } & \multicolumn{2}{|c|}{ Candidate vaccines (no. and \%) } \\
\hline 1 dose & & 10 & $17 \%$ \\
\hline Day 0 & & 10 & \\
\hline 2 doses & & 37 & $62 \%$ \\
\hline Day $0+14$ & & 5 & \\
\hline Day 0 + 21 & & 14 & \\
\hline Day $0+28$ & & 18 & \\
\hline 3 doses & & 1 & $2 \%$ \\
\hline \multicolumn{2}{|l|}{ Day $0+28+56$} & 1 & \\
\hline \multicolumn{2}{|l|}{ TBD / No Data (ND) } & 12 & $20 \%$ \\
\hline & & 60 & \\
\hline \multicolumn{4}{|c|}{ Route of admininstration } \\
\hline Oral & & 3 & $5 \%$ \\
\hline Injectable & & 51 & $85 \%$ \\
\hline SC & Sub cutaneous & 2 & $3 \%$ \\
\hline ID & Intra dermal & 3 & $5 \%$ \\
\hline IM & Intra muscular & 46 & $77 \%$ \\
\hline \multicolumn{2}{|l|}{ TBD / No Data (ND) } & 6 & $10 \%$ \\
\hline
\end{tabular}

Table no. 2 - Dosage, schedule and route of administration for candidate vaccines in clinical evaluation stage, according to the WHO - 29.12.2020 [4]

Each country has established a vaccination strategy for the population, prioritizing groups of people that are at risk. Thus, in Germany, in the first group, with high priority, were included [5]:

1. People over the age of 80 .

2. Care staff working in senior citizens centers, or who regularly deal with the elderly or the mentally ill.
3. Medical personnel at high risk of exposure to COVID-19, especially those working in intensive care units, emergency units and first-line health care providers.

4. Medical personnel treating patients at high risk of death with COVID-19. 
OBJECTIVES: Given that medical staff is included in the priority vaccination group in Romania, the present study aimed to assess the acceptability of vaccination by medical staff, as well as the intention to vaccinate against SARS-CoV-2 among them.

MATERIAL AND METHOD: The study was conducted between Novmber $3^{\text {rd }}$ and $12^{\text {th }} 2020$ by distributing in medical personnel's online professional groups an anonymous questionnaire on the acceptance by the medical staff of vaccination in general and of COVID-19 vaccination in particular.

\section{RESULTS AND DISCUSSION}

612 people, 164 nurses and 448 doctors answered the questionnaire. 207 of the responding doctors work in the hospital, 103 in the outpatient department, 76 in school medical offices and 62 in family doctors offices.

$92.32 \%$ of the participants in the study state that they support vaccination, in general (Table no. 3), with percentages ranging from $84.15 \%$ among nurses to $100 \%$ among family doctors who responded to this question.

\begin{tabular}{|l|c|c|}
\hline & Yes & $\mathbf{\%}$ \\
\hline Family doctor & 62 & $100,00 \%$ \\
\hline School physician & 73 & $96,05 \%$ \\
\hline Hospital doctor & 198 & $95,65 \%$ \\
\hline Ambulatory care doctor & 94 & $91,26 \%$ \\
\hline Nurse & 138 & $84,15 \%$ \\
\hline Total & $\mathbf{5 6 5}$ & $\mathbf{9 2 , 3 2 \%}$ \\
\hline
\end{tabular}

Table no.3 - Do you support vaccination in general?
An Avangarde survey, conducted in December 2020 on a significant sample of the general population of Romania shows that $38 \%$ of respondents say they are pro-vaccination in general, $20 \%$ against vaccination, $25 \%$ say they do not have a clear position or are not interested and $17 \%$ do not know or do not answer. [7] The differences between the pro-vaccination attitude of the medical staff and of the general population are significantly increased and reflect the awareness of the medical staff of the importance immunization has for public health.

Seeing that there are studies that have shown a strong association between influenza vaccination and the intention to vaccinate against COVID-19 among the general population [8], we wanted to see if this association is also observed among medical workers in Romania.

Thus, $43.3 \%$ of the medical staff who participated in the study stated that they had been vaccinated against influenza this season; the percentage of nurses who were vaccinated was the lowest $(23.17 \%)$, while the percentage of family doctors was the highest. (74.19\%) (Table no. 4).

\begin{tabular}{|l|c|c|}
\hline & Yes & \% \\
\hline Family doctor & 46 & $74,19 \%$ \\
\hline Ambulatory care doctor & 59 & $57,28 \%$ \\
\hline Hospital doctor & 96 & $46,38 \%$ \\
\hline School physician & 26 & $34,21 \%$ \\
\hline Nurse & 38 & $23,17 \%$ \\
\hline Total & $\mathbf{2 6 5}$ & $\mathbf{4 3 , 3 0 \%}$ \\
\hline
\end{tabular}

Table no. 4. - Have you been vaccinated against the flu this season?

\begin{tabular}{|c|c|c|c|c|c|c|}
\hline & \multicolumn{3}{|c|}{$\begin{array}{l}\text { Will you get vaccinated against } \\
\text { COVID-19? }\end{array}$} & \multirow[t]{2}{*}{ Total } \\
\hline & & & no & yes & I don't know & \\
\hline \multirow{4}{*}{$\begin{array}{l}\text { Have you been vaccinated } \\
\text { against the flu this season? }\end{array}$} & & Count & 19 & 177 & 69 & 265 \\
\hline & yes & $\begin{array}{l}\% \text { within „Have you been } \\
\text { vaccinated against the flu this } \\
\text { season?” }\end{array}$ & $7.2 \%$ & $66.8 \%$ & $26.0 \%$ & $100.0 \%$ \\
\hline & & Count & 98 & 113 & 136 & 347 \\
\hline & no & $\begin{array}{l}\% \text { within „Have you been } \\
\text { vaccinated against the flu this } \\
\text { season?” }\end{array}$ & $28.2 \%$ & $32.6 \%$ & $39.2 \%$ & $100.0 \%$ \\
\hline
\end{tabular}


Articole științifice

\begin{tabular}{|ll|c|c|c|c|}
\hline & & \multicolumn{2}{|c|}{ Will you get vaccinated against } & \multirow{2}{*}{ COVID-19? } \\
\cline { 2 - 4 } Total & Count & 117 & 290 & 205 & 612 \\
& $\begin{array}{l}\text { \% within „Have you been } \\
\text { vaccinated against the flu this } \\
\text { season?" }\end{array}$ & $19.1 \%$ & $47.4 \%$ & $33.5 \%$ & $100.0 \%$ \\
\hline
\end{tabular}

Table no. 5. Have you been vaccinated against the flu this season? $X$ Will you get vaccinated against COVID-19? Cross tabulation

In the case of our study, there is also a close correlation between influenza vaccination and the intention to vaccinate against COVID-19 in medical staff: $\chi^{2}=79.80, \mathrm{p}<0.001$ (Table no. 5).

The next qeustion in our survey, „Do you think that COVID-19 vaccination should be mandatory?", generated the following answers: $31.2 \%$ of the respondents answered in the affirmative while $68.8 \%$ of the medical staff in the study considered that COVID-19 vaccination should not be mandatory (Table no. 6).

\begin{tabular}{|l|c|c|}
\hline & Da & Nu \\
\hline Nurses & 45 & 119 \\
\hline Doctors & 146 & 302 \\
\hline Total & 191 & 421 \\
\hline
\end{tabular}

Table no. 6. - Do you think COVID-19 vaccination should be mandatory?

Regarding the groups of people who should be vaccinated as a priority, the medical staff participating in the study considered that medical staff, people with risk factors and those in residential centers should be vaccinated as a priority (Table 7).

\begin{tabular}{|l|l|l|}
\hline \multicolumn{1}{|c|}{ Who do you think should be vaccinated against COVID-19 first? } & \multicolumn{1}{|c|}{ nr. } & \multicolumn{1}{|c|}{$\%$} \\
\hline Medical staff & 438 & $71,6 \%$ \\
\hline Immunosuppressed persons / with risk factors & 409 & $66,8 \%$ \\
\hline Senior care centers residents & 235 & $38,4 \%$ \\
\hline Elders & 16 & $2,6 \%$ \\
\hline Others (politicians, police force, teachers, retail workers) & 42 & $6,8 \%$ \\
\hline
\end{tabular}

Table no. 7 - Priority groups for COVID vaccination (as indicated by respondents)

$80 \%$ of the medical staff supports the vaccination against COVID-19, in general (Table no. 8 ).

\begin{tabular}{|l|l|l|}
\hline & \multicolumn{1}{|c|}{ Yes } & \multicolumn{1}{c|}{$\%$} \\
\hline Family doctor & 56 & $90,32 \%$ \\
\hline School physician & 66 & $86,84 \%$ \\
\hline Hospital doctor & 169 & $81,64 \%$ \\
\hline Ambulatory care doctor & 83 & $80,58 \%$ \\
\hline Nurse & 115 & $70,12 \%$ \\
\hline Total & $\mathbf{4 8 9}$ & $\mathbf{7 9 , 9 0 \%}$ \\
\hline
\end{tabular}

Table no. 8 - Do you support COVID-19 vaccination in general?

There is a statistically significant difference between the acceptance of vaccination by doctors and nurses, $\chi^{2}=13.34, p<0.001$ (Table no. 9), but there is no statistically significant difference between the acceptance of vaccination, in general, between doctors in hospitals, outpatient clinics, family medicine offices / schools medical offices., $\chi^{2}=3.86, p=0.277$ (Table no. 10). 


\begin{tabular}{|c|c|c|c|c|c|}
\hline & & & \multicolumn{2}{|c|}{$\begin{array}{c}\text { Do you support COVID-19 } \\
\text { vaccination in general? }\end{array}$} & \multirow[t]{2}{*}{ Total } \\
\hline & & & no & yes & \\
\hline $\begin{array}{l}\text { You are: } \\
\text { Total }\end{array}$ & $\begin{array}{l}\text { Nurses } \\
\text { Doctors }\end{array}$ & $\begin{array}{l}\text { Count } \\
\text { \% within: } \\
\text { Count } \\
\text { \% within: } \\
\text { Count } \\
\text { \% within: }\end{array}$ & $\begin{array}{c}49 \\
29.9 \% \\
74 \\
16.5 \% \\
123 \\
20.1 \% \\
\end{array}$ & $\begin{array}{c}115 \\
70.1 \% \\
374 \\
83.5 \% \\
489 \\
79.9 \% \\
\end{array}$ & $\begin{array}{c}164 \\
100.0 \% \\
448 \\
100.0 \% \\
612 \\
100.0 \%\end{array}$ \\
\hline
\end{tabular}

Table no. 9 - Do you support COVID-19 vaccination in general? Nurses / doctors correlation

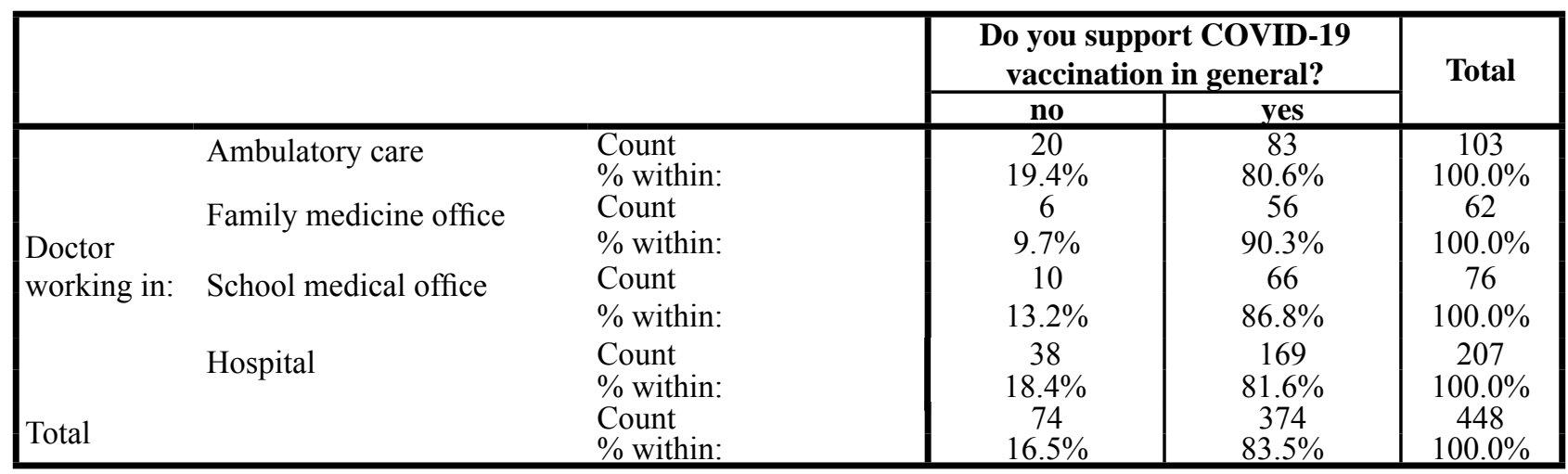

Table no. 10. Do you support COVID-19 vaccination in general? Correlation for doctors

The intention of vaccination against COVID-19 undecided, while $19.12 \%$ say they will not get vacciof the medical staff who participated in the study is nated against COVID-19 (Table no. 11). $47.39 \%$. A proportion of $33.5 \%$ of respondents are

\begin{tabular}{|l|c|c|c|}
\hline & Yes & Nu & I don't know \\
\hline Ambulatory care doctor & $59(57,28 \%)$ & $18(17,48 \%)$ & $26(25,24 \%)$ \\
\hline Hospital doctor & $112(54,11 \%)$ & $42(20,29 \%)$ & $53(25,60 \%)$ \\
\hline Family doctor & $32(51,61 \%)$ & $6(9,68 \%)$ & $24(38,71 \%)$ \\
\hline School physician & $36(47,37 \%)$ & $10(13,16 \%)$ & $30(39,47 \%)$ \\
\hline Nurse & $51(31,10 \%)$ & $41(25,00 \%)$ & $72(43,90 \%)$ \\
\hline Total & $\mathbf{2 9 0 ( 4 7 , 3 9 \% )}$ & $\mathbf{1 1 7}(\mathbf{1 9 , 1 2 \% )}$ & $\mathbf{2 0 5}(\mathbf{3 3 , 5 0 \% )}$ \\
\hline
\end{tabular}

Tabelul nr. 11. Intenția de vaccinare anti-COVID-19

Compared to the Avangarde study from December 2020, in which $30 \%$ of the general population of Romania declares that they are determined to get vaccinated against COVID-19, 29\% are undecided and 29\% refuse vaccination [7], it is observed that even in the case of vaccination intention against COVID -19 the percentage of medical staff who want to get vaccinated is much higher than in the general population.

Comparing with the data published in November 2020, by different County Public Health Directorates, regarding a first estimate of the intention to vaccinate of the medical staff, we find that these figures are comparable to those in our study, and are even higher than the intention to vaccinate among the general population. Thus, in Alba county, 60\% of the medical staff said that they accept the vaccination: hospital doctors $-70 \%$, family doctors $-88 \%$, nurses $-45.8 \%$, orderly $-45.45 \%$. In Iași county, $60 \%$ of doctors, $47 \%$ of nurses, $43 \%$ of orderly and $46 \%$ of caregivers said they want to be vaccinated, and at Colentina Hospital in Bucharest, out of 1390 employees, 890 opted for anti-Covid vaccination, ie a percentage of $63.57 \%$ [9].

Even regarding the intention to vaccinate against COVID-19, there is a statistically significant 
difference between physicians and nurses participating in the study, $\chi^{2}=23.84, p<0.001$, the percentage of doctors who state they will get vaccinated being significantly higher than that of nurses (Table no. 12), while among doctors working in hospitals, outpatient clinics, familiy medicine offices, school medical offices, there is no statistically significant difference in the intention to vaccinate, $\chi^{2}=10.82, p=0.094$ (Table no. 13).

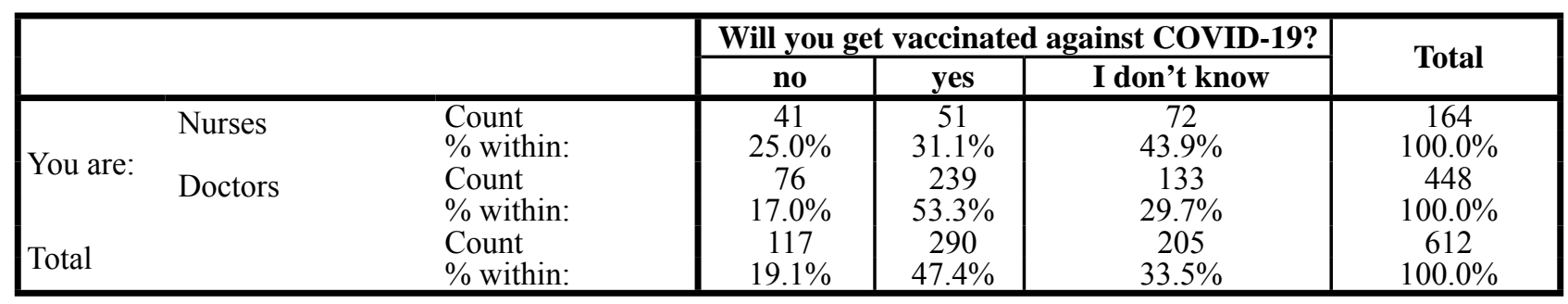

Table no. 12 - Will you get vaccinated against COVID-19? Nurses / doctors correlation

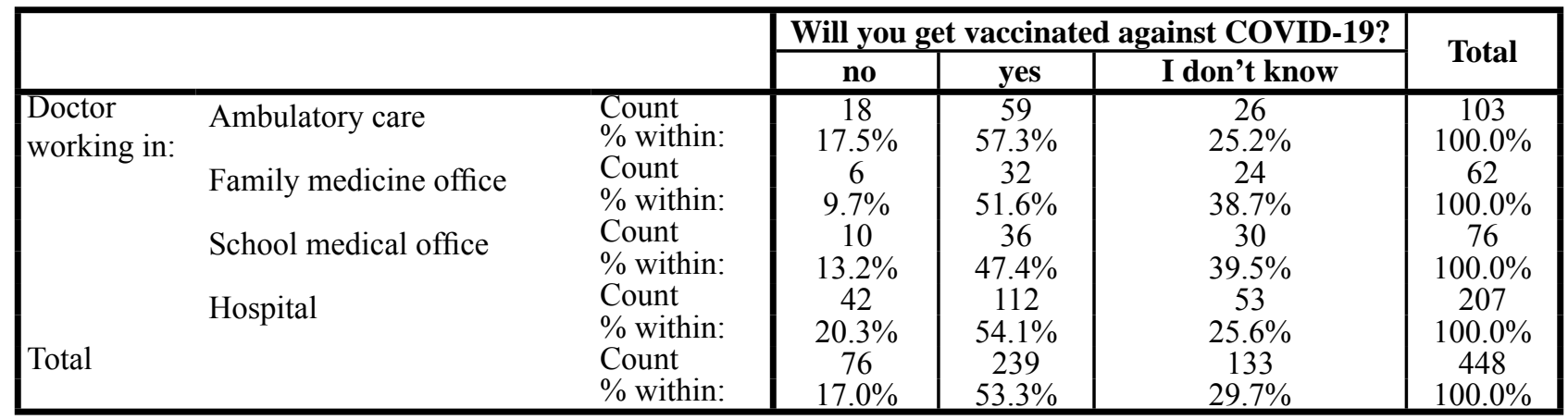

Table no. 13 - Will you get vaccinated against COVID-19? Correlation for doctors

The findings of a study on the intention to get vaccinated against COVID-19 in 13,426 respondents in 19 countries show that $31.9 \%(4,286$ of 13,426$)$ would totally agree, and $17.9 \%(2,411$ of 13,426$)$ would totally disagree with the acceptance of a safe and effective vaccine provided by the governments of those countries. [10].

In the United Kingdom, $64 \%$ of study participants said they would get vaccinated against COVID-19, 27\% were unsure and 9\% said they did not want to be vaccinated [11]. The reasons for which the medical staff in the study state that they would not get vaccinated against COVID-19 / do not know if they would get vaccinated are:

\begin{tabular}{|l|c|}
\hline $\begin{array}{l}\text { They don't think there is enough scientific data on } \\
\text { the efficacy and safety of the vaccine }\end{array}$ & 221 \\
\hline Because of the potential side effects of the vaccine & 64 \\
\hline They have already been confirmed with COVID-19 & 26 \\
\hline They don't trust vaccines in general & 6 \\
\hline Other & 5 \\
\hline Total & 322 \\
\hline
\end{tabular}

Hesitation on vaccination is generally a growing problem in recent years, and studies have tried unsuccessfully to find predictable indicators of hesitation in vaccination [12].

It is important to distinguish between those who oppose vaccination and those who have relevant concerns and questions about a particular vaccine, its safety and efficacy [13], as transparency in communication can change uncertainties and increase vaccination intentions.

\section{CONCLUSIONS}

The medical staff participating in the study accept the vaccination, in general, and the antiCOVID-19 vaccination, in particular.

It is considered that anti-COVID-19 vaccination in Romania should not be mandatory, and priority groups for vaccination should be represented by: medical staff, people with risk factors and people in residential centers. 
The intention of vaccination against COVID-19 of the medical staff is close to $50 \%$, being superior to that of the general population. An important percentage of the medical staff, $33.5 \%$, was not decided, at the beginning of November 2020, whether to get vaccinated or not.

\section{BIBLIOGRAFIE}

1. Randolph HE, Barreiro LB. Herd immunity: Understanding COVID-19. Immunity. 2020; 52 (May 19):737-741

2. Altmann DM, Douek DC, Boyton RJ. What policy makers need to know about COVID-19 protective immunity. The Lancet. 2020; 395 (May 16): 1527-1529

3. https://ec.europa.eu/health/sites/health/files/vaccination/ docs/2020_strategies_deployment_en.pdf - accesat 30.12.2020

4. https://www.who.int/publications/m/item/draft-landscape-of-covid-19-candidate-vaccines - accesat 29.12.2020

5. https://www.dw.com/en/covid-german-regulations-onwho-gets-vaccine-first/a-55987647- accesat 30.12.2020

6. https://vaccinare-covid.gov.ro/vaccinarea-sars-cov-2/ procesul-de-vaccinare-in-romania/ - accesat 30.12.2020

7. https://moldova.europalibera.org/a/sondaj-avangardedoar-30-dintre-rom $\% \mathrm{C} 3 \% \mathrm{~A} 2$ ni-spun-c $\% \mathrm{C} 4 \% 83$-se-vor-vaccina70-se-opun-unei-noi-carantine-generale-/31014822.html- accesat 29.12.2020

8. Susan M. Sherman, Louise E. Smith, Julius Sim, Richard Amlôt, Megan Cutts, Hannah Dasch, G James Rubin
\& Nick Sevdalis (2020) COVID-19 vaccination intention in the UK: results from the COVID-19 vaccination acceptability study (CoVAccS), a nationally representative cross-sectional survey, Human Vaccines \& Immunotherapeutics, DOI: 10.1080/21 645515.2020 .1846397

9. https://romania.europalibera.org/a/sunt-medicii-reticen $\% \mathrm{C} 8 \% 9 \mathrm{Bi}-\mathrm{fa} \% \mathrm{C} 8 \% 9 \mathrm{~B} \% \mathrm{C} 4 \% 83$-de-vaccinarea-anti-covid-ce-arat $\%$ C4\%83-primele-date/30959102.html - accesat 30.12.2020

10. Lazarus JV, Ratzan SC, Palayew A. et al. A global survey of potential acceptance of a COVID-19 vaccine. Nat Med (2020). https://doi.org/10.1038/s41591-020-1124-9 Published 20 October 2020

11. Sherman SM, Smith LE, Sim J, Amlôt R, Cutts M, Dasch H, Rubin GJ, Sevdalis N. COVID-19 vaccination intention in the UK: results from the COVID-19 vaccination acceptability study (CoVAccS), a nationally representative cross-sectional survey, Human Vaccines \& Immunotherapeutics (2020). DOI: 10.10 80/21645515.2020.1846397

12. Larson HJ, Jarrett C, Eckersberger E, Smith DM, Paterson $\mathrm{P}$. Understanding vaccine hesitancy around vaccines and vaccination from a global perspective: a systematic review of published literature, 2007-2012. Vaccine. 2014 Apr 17;32(19):21509. doi: 10.1016/j.vaccine.2014.01.081. Epub 2014 Mar 2. PMID: 24598724

13. MacDonald NE; SAGE Working Group on Vaccine Hesitancy. Vaccine hesitancy: definition, scope and determinants. Vaccine 2015; 33: 4161-6 